\title{
Durability of reinforced PVC-P geomembranes installed in reservoirs in eastern Spain
}

\author{
M. Blanco ${ }^{1}$, N. Touze-Foltz ${ }^{2}$, M. Pérez Sánchez ${ }^{3}$, M. Redon-Santafe ${ }^{4}$, F. J. Sánchez Romero ${ }^{5}$, \\ J. B. Torregrosa Soler ${ }^{6}$ and F. A. Zapata Raboso ${ }^{7}$ \\ ${ }^{1}$ Head of the Material's, Department of the Central Laboratory of Structures and Materials, CEDEX, \\ 28014, Madrid, Spain, E-mail: Manuel.Blanco@cedex.es \\ ${ }^{2}$ Head of the Geosynthetics Laboratory, Hydrosystems and Bioprocesses Research Unit, Irstea, 92761, \\ Antony Cedex, France, E-mail: nathalie.touze@irstea.fr \\ ${ }^{3}$ Assistant Professor, Department of Hydraulics Engineering and Environment, Universitat Politécnica de \\ Valencia, UPV.03801 Alcoy, Spain, E-mail: mopesan1@upv.es \\ ${ }^{4}$ Assistant Professor, Department of Agrifood and Rural Engineering, Universitat Politécnica de Valencia, \\ UPV. 46022, Valencia, Spain, E-mail: miresan@agf.upv.es (corresponding author) \\ ${ }^{5}$ Assistant Professor, Department of Agrifood and Rural Engineering, Universitat Politécnica de Valencia, \\ UPV. 46022, Valencia, Spain, E-mail: fcosanro@agf.upv.es \\ ${ }^{6}$ Associate Professor, Department of Agrifood and Rural Engineering, Universitat Politécnica de Valencia, \\ UPV. 46022, Valencia, Spain, E-mail: jbtorreg@fis.upv.es \\ ${ }^{7}$ PhD, PE Irrigation Waterworks Section - Agriculture, Environment, Climate Change and Rural \\ Development Council of Valencia.03003, Alicante, Spain, E-mail: zapata_fra@gva.es
}

Received 06 October 2016, revised 02 October 2017, accepted 10 October 2017, published 28 February 2018

ABSTRACT: The aim of this paper is to study the durability of polyvinyl chloride (PVC-P) geomembranes reinforced with a synthetic fabric in hydraulic works in the Spanish Mediterranean basin. Therefore, a set of six geomembranes installed in irrigation reservoirs for 18-31 years were analysed. The initial characteristics of the geomembranes were determined to verify fulfilment of the Spanish regulations in force at the time. The characteristics were then assessed, and the results were interpreted with reference to the loss of plasticisers, tensile characteristics, foldability at low temperatures, dynamic impact resistance, puncture resistance, seam strength, reflected optical microscopy (ROM) and scanning electron microscopy (SEM). Additionally, the identification of the plasticisers in the geomembranes involved Fourier transform infrared spectroscopy (FTIR), gas chromatography (GC) and mass spectrometry (MS) tests. For the analysed samples, the loss of plasticisers was significant, ranging from $71.0 \%$ to $84.3 \%$. However, the tensile strength results indicated current, regular waterproof working performances in the reservoirs. The results suggest that the durability of PVC-P geomembranes is a function of the loss of plasticisers and the state of the synthetic reinforced fibres.

KEYWORDS: Geosynthetics, Geomembrane, PVC-P, Waterproofing, Water reservoir, Durability

REFERENCE: Blanco, M., Touze-Foltz, N., Pérez Sánchez, M., Redon-Santafe, M., Sánchez Romero, F. J., Torregrosa Soler, J. B. and Zapata Raboso, F. A. (2018). Durability of reinforced PVC-P geomembranes installed in reservoirs in eastern Spain. Geosynthetics International, 25, No. 1, 85-97. [https://doi.org/10.1680/jgein.17.00035]

\section{INTRODUCTION}

The use of synthetic geomembranes in hydraulic works began in the 1940s, and development increased in the 1960s and 1970s. Butyl rubber (IIR) geomembranes were used for waterproofing in the 1930s, and polyvinyl chloride linings started to appear in the 1940s. There were some problems with the first generation of polymer geomembranes, such as the minimal resistance of IIR to ozone and the brittleness and propensity to cracking of PVC-P, which mainly occurs when used in contact with bituminous materials (Noval 2015a).

The first documented application of a polymer geomembrane was for waterproofing the ContradaSabetta dam in Italy (Cazzuffi 1987; Cazzuffi et al. 2010). The geomembrane that was used was polyisobutylene (PIB), and it was applied in 1959. In its Bulletin No 78, the International Commission on Large Dams (ICOLD 1991) cited the Kualapuu Reservoir in Molokai (Hawaii) as the first reservoir to be 
waterproofed using an IIR synthetic geomembrane in 1969.

The use of synthetic geomembranes in hydraulic works first arrived in Spain in the 1970s in the Southeast of the peninsula, specifically in the Ibi district of Alicante province, where IIR-based elastomeric barriers were installed (Blanco 2005). Previously, the reservoirs had used liquid waterproofing systems, for example, at E1 Saltadero. Additionally, low-density polyethylene (LDPE) films were applied in buried systems, and some have survived perfectly, fulfilling their function to the present day. This is the case in the El Fraile reservoir (south of Tenerife island) and Plá Mateos (Alicante). Before this, albeit uncommonly, bituminous geomembranes modified with rubber were used in some dams in the Pyrenees, such as the Aiguamoix dam in Lerida. In 1968, the Odiel Perejil dam in Campofrío (Huelva province) was built using a thermoplastic chlorinated polyethylene (CPE) geomembrane (ICOLD 2010). In 2002, a survey was carried out to establish the performance of geomembranes over time, and the results showed excellent preservation of the membranes (Blanco and Zaragoza 2003). In 1974, the Matavacas irrigation weir (Sanlúcar de GuadianaHuelva) was waterproofed with an IIR synthetic geomembrane, which is still in good condition apart from the joints between the sheets (de Cea et al. 2003; Blanco et al. 2010).

PVC-P is considered the successor to IIR, and it is resistant to ozone. It was initially introduced as a synthetic thread reinforcement (Crespo 2011) and then as a homogenous material (Blanco et al. 2013a) or fibreglass insertion (Blanco et al. 2016a). This material was widely supported for use in Mediterranean countries, for example, Italy (Cazzuffi 2013).

Consequently, high-density polyethylene (HDPE) geomembranes began to be used in some waterproofed reservoirs in Castilla-León and the Canary Islands (Noval et al. 2014a, 2014b).

Next, a move into the field of elastomers began with the appearance of ethylene propylene diene monomer rubber (EPDM), which contains a minimum number of double bonds in its side chain and is not attacked by atmospheric ozone (Noval et al. 2014c, 2015; Blanco et al. 2015).

In Spain, the installation of PVC-P geomembranes was highest in the last two decades of the past century. The most widespread areas of use were in the southeast of the peninsula and the Canary Islands because of the large quantity of agricultural irrigation reservoirs (Amigó and Aguiar 1994; Aguiar and Blanco 1995; Blanco et al. 2003a, 2012).

Nevertheless, PVC-P geomembrane may have some disadvantages, because the material can occasionally deteriorate relatively quickly due to the loss of plasticisers. In building construction applications, the installation of a PVC-P lining sheet over a bituminous geomembrane leads to accelerated depletion because of the interactions between the bitumen components (maltenes, asphaltenes, oils) and those of the geomembrane (resins and additives).

By the 1980s, PVC-P was widely used in the region of Valencia, and some of those reservoirs still have the same waterproofing system currently (Blanco et al. 2016b). In other cases, the reservoirs were re-waterproofed using a different procedure (Méndez et al. 2008).

In this paper, we analyse the behaviour over time of six PVC-P geomembranes reinforced with polyester fabric. Their ages range from 18 to 31 years, and they were all installed in irrigation reservoirs located in the Alicante province (southeast Spain). The survey was carried out in the following reservoirs: El Hondón de las Nieves, El Rollo, Plá Aceituna, La Caseta de Mira, El Cid-III and El Rabosero. The aim of this paper is to demonstrate that a PVC-P geomembrane reinforced with synthetic thread fabric remains effective despite the fact that its loss of plasticisers is greater than $50 \%$. Therefore, based on experience with exposed PVC liners in Spain installed according to European practice, their durability is not only dependent on the loss of plasticisers but also on the condition of the textile reinforcement.

\section{THE RESERVOIRS}

\subsection{Location}

The studied reservoirs are El Hondón de las Nieves, El Rollo, Plá Aceituna, La Caseta de Mira, El Cid-III and El Rabosero. All are located in Alicante province (southeast Spain) (Supplemental Graphical Data). All these reservoirs have been waterproofed with a PVC-P geomembrane reinforced with a synthetic thread fabric. The installation of the geomembranes ranges from 1984 (Cid III) to 1997 (Caseta de Mira). The technical characteristics of the reservoirs are shown in Table 1 and include the location, capacity, elevation, height, crest perimeter and date of installation.

\subsection{Climate}

The exposure conditions of all the geomembranes are very similar, since all of them were installed on uncovered reservoirs. Additionally, their site locations share similar semi-arid climatic conditions characterized by high annual solar radiation (approximately $2700 \mathrm{~h}$ of sunlight per year) and severe summer drought. The total annual precipitation is less than $400 \mathrm{~mm}$, which comes mainly in the autumn and the spring, and shows an irregular rainfall distribution out of sync with the times of maximum irrigation needs.

The maximum ultraviolet index for clear weather in Alicante is between 4.5 and 6.5 , which is relatively significant in terms of the scale of 0.5 (low UV) to 14.5 (extreme UV) (UNEP 2007).

\subsection{PVC-P geomembrane}

Reservoirs were lined with a $1.50 \mathrm{~mm}$ thick PVC-P geomembrane from VICON plastic manufacturing using the 'impregnation' process. Although the original composition of the geomembranes is unknown, a typical composition is 50-70\% PVC resin, 25-35\% plasticisers and $2-5 \%$ other additives, which include UV light absorbents such as carbon black, pigments such as titanium dioxide, stabilizers such as calcium stearate, and fillers 
Table 1. Characteristics of the reservoirs waterproofed with PVC-P

\begin{tabular}{|l|l|l|l|l|l|l|}
\hline Reservoir & Hondón de las Nieves & El Rollo & Plá Aceituna & Caseta de Mira & Cid-III & El Rabosero \\
\hline Location & Hondón de las Nieves & Aspe & Agost & Agost & Monforte del Cid & Aspe \\
Capacity $\left(\mathrm{m}^{3}\right)$ & 1213280 & 536000 & 118132 & 269717 & 531810 & 240772 \\
Elevation $(\mathrm{m})$ & 19.50 & 16.00 & 8.25 & 9.00 & 12.0 & 12.80 \\
Height of crest $(\mathrm{m})$ & 464 & 399 & 388 & 419 & 404 & 260 \\
Crest perimeter $(\mathrm{m})$ & 1068 & 834 & 535 & 780 & & 950 \\
- Slope gradient & $1.50: 1$ & $1.50: 1$ & $1.30: 1$ & $1.75: 1$ & & $1.50: 1$ \\
- Exterior & $2.50: 1$ & $1.50: 1$ & $2.50: 1$ & $2.00: 1$ & $2.50: 1$ & $1.50: 1$ \\
- Interior & 1987 & 1994 & 1997 & 1984 & $3.00: 1$ \\
Geomembrane installation year & 1990 & \multicolumn{5}{|l}{} \\
\hline
\end{tabular}

such as calcium carbonate (Koerner et al. 2005; Blanco 2015).

\section{EXPERIMENTAL}

The experimental method followed the guidelines of European regulation EN 13361 (AENOR 2013a). All samples were extracted from the northern slopes of the reservoirs in the crest area, which faces south and receives the most solar radiation (Aguiar et al. 2003; Blanco et al. 2003b; Noval et al. 2014d). In the case of the Hondón de las Nieves reservoir, a sample was also taken from the intermediate area on the northern slope, which is sometimes covered by water and sometimes in contact with solar radiation. The exhumed samples represent the worst-case scenario, since most of the installed geomembranes perform better under less solar radiation.

First, the original characteristics of all the lining systems were determined. These values are shown in Table 2. It should be noted that the previously existing regulations included tests that have currently fallen out of use, for example, water behaviour and plasticiser migration.

The water behaviour was tested in accordance with regulation UNE 53 028, method B (AENOR 1990), which has since been modified. The test is used to assess the absorption of water by the geomembrane and the extraction of additives by the water; the results for both the absorption and extraction were obtained over 1 to 6 days. The water behaviour fundamentally affected the dimensional stability of the geomembranes.

Plasticiser migration was tested in accordance with regulation UNE 53095 (AENOR 1981) using circular test specimens $60 \mathrm{~mm}$ in diameter at a temperature of $(50 \pm 1)^{\circ} \mathrm{C}$ and using expanded polyethylene as the contact material. The test sought to determine the loss of plasticiser in contact with a solid at a certain temperature. This test was mandatory in both the first draft of the current European regulation and in the Swiss and Spanish regulations. However, after some years, it was determined that the laboratory values had no relation to the field installation results. For this reason, this test does not appear in the current regulations.

In the case of these geomembranes, very high migration values were initially observed, and some years later, this
Table 2. Geomembrane characteristics before installation

\begin{tabular}{|l|c|}
\hline Characteristic & Value \\
\hline Plasticiser content (\%) & 34.1 \\
Traction resistance (N/50 mm) & 2208 \\
$\quad$ Longitudinal & 2203 \\
$\quad$ Transversal & \\
Elongation at maximum strain (\%) & 18 \\
$\quad$ Longitudinal & 33 \\
Transversal & 531 \\
Puncture resistance (N/mm) & 450 \\
$\quad$ External side & \\
Internal side & 8 \\
Plunger displacement before perforation (mm) & 5 \\
External side & \\
Internal side & 1800 \\
Seam resistance (N/50 mm) & 438 \\
$\quad$ By traction & 4.06 \\
Peeling & 4.00 \\
Migration of plasticisers (\%) & 9.60 \\
Water behaviour & 0.19 \\
Absorption (\%) & 0.30 \\
1 day & \\
6 days & \\
Extraction (\%) & \\
1 day & \\
6 days & \\
\hline
\end{tabular}

value had not increased. However, the authors are aware that other materials that initially showed low migration values experienced high levels of migration when they were finally installed in waterworks (Blanco and Aguiar 1993).

\subsection{Plasticisers}

\subsubsection{Content}

The determination of the plasticiser content levels was carried out in accordance with the Spanish regulations in force at the time, UNE 104306 and ASTM D2124 (AENOR 2000; ASTM D2124). Extraction with ethyl ether removes all low molecular weight organic products, but it does not extract the vinyl macromolecule and non-organic materials. However, it does extract other additives distinct from the plasticiser, such as UV light absorbents and antioxidants. For this reason, the loss of plasticisers calculation uses a correction in accordance with the scientific literature (Giroud 1995). 


\subsubsection{Identification}

Once the plasticisers were isolated, the process of identification began, using Fourier transform infrared spectroscopy (FTIR) (Ortega and Blanco 1982; Blanco et al. 1989). The identification is based on the presence of absorption bands that are characteristic of different organic groups. The analysis was performed using a Nicolet 310 spectrometer.

Then, to complete the identification of the additive, gas chromatography (GC) was used in combination with mass spectrometry (MS). An Agilent 6890 N Network was used with a capillary column of phenyl methylpolysiloxane $\mathrm{DB} \%$-MS $(30 \mathrm{~m} \times 0.25 \times 0.25)$ coupled with an Agilent 5793 MSD quadrupole mass detector system in electron impact mode. The GC allows us to observe and separate the products in the plasticiser, and the MS identifies the elucidated fractions (Blanco et al. 2008, 2009).

\subsection{Folding at low temperatures}

PVC geomembrane specimens were folded in accordance with the standard EN 495-5 (AENOR 2013b) method. This test involved maintaining the specimens at $-20^{\circ} \mathrm{C}$ for $5 \mathrm{~h}$, after which the specimens were folded at an angle of $180^{\circ}$ and held at this angle for $3 \mathrm{~s}$. The specimens were subsequently inspected for any evidence of cracks, fissures or any other signs of surface imperfections.

The temperature used for the folding tests depended on the geomembrane material and its macromolecular characteristics. Thus, the objective of this test was to assess the suitability of the material, instead of reproducing the temperature conditions the geomembrane would be subjected to during its service life. The dimensions of the test specimens were $200 \times 200 \mathrm{~mm}$.

\subsection{Dynamic impact}

The dynamic impact test is a useful parameter for evaluating the capacity of a geomembrane to resist punctures caused by stones, pebbles, or foreign objects that may be thrown into the reservoir by vandals.

This test was performed per the standard EN 13361 (AENOR 2013a) method. A geomembrane passes this test if it is not perforated after dropping a $0.5 \mathrm{~kg}$ plunger five times into a hemisphere $12.7 \mathrm{~mm}$ in diameter from a height of $500 \mathrm{~mm}$. The concave surface of the hemisphere is placed facing upwards. The presence of punctures was determined by a watertight test.

\subsection{Puncture resistance}

The static puncture resistance and displacement of the plunger before the perforation were measured per the UNE 104317 (AENOR 2011) method. This measurement method was developed by CEDEX and is now part of the standards applied by AENOR (Blanco et al. 1996). The method uses an INSTRON dynamometer (model 556). The upper clamps have a cylindrical rod with an irregular pyramid shape ending that allows test specimens to be fitted over a hollow device in the lower part. Ten circular samples (five for each side) that were $50 \mathrm{~mm}$ in diameter were tested at low speeds $(5 \mathrm{~mm} / \mathrm{min})$. A larger plunger displacement prior to perforation indicated a better puncture resistance.

\subsection{Tensile characteristics}

The tensile characteristics of the specimens were measured per the standard EN ISO 527-3 (AENOR 1996) method using an INSTRON dynamometer (model 5569). The displacement speed was $100 \mathrm{~mm} / \mathrm{min}$. The tensile characteristics were determined both longitudinally and transversally. Rectangular test specimens were used because the geomembranes were reinforced with synthetic threads. The polyester fabric used for the reinforcement is responsible for the load and elongation performances, which were measured at the maximum load point. The tensile strength results are expressed as N/50 mm, which is the width of the rectangular test specimen used.

\subsection{Seam resistance}

Seam resistance tests for both the shear resistance and peeling resistance were carried out using an INSTRON dynamometer, model 5569, with a clamp separation speed of $100 \mathrm{~mm} / \mathrm{min}$ and rectangular test specimens (EN 13 361).

The tensile method is considered a valid qualitative approach to assess the behaviour of the seams between geomembranes. The resulting values reflect the tensile strength in the transverse direction. The specimens broke at the edge or close to the seam, which confirmed the acceptable findings of the test.

Using the allowed material quantity, the peeling resistance test was carried out. The quantitative nature of this test allows comparisons to be made between different materials or between the same materials from different reservoirs or from different areas of the same reservoir when appropriate.

\subsection{Reflection optical microscopy (ROM) and scanning electron microscopy (SEM)}

The microscopic structures of the geomembranes were determined using ROM and SEM. Microscopic evaluations of the geomembranes were carried out according to the literature (Blanco et al. 2002; Soriano et al. 2010, 2012).

ROM was assessed using a LEICA optical microscope, model DMRX, which was equipped with an automatic photographic system. Microphotographs were taken at $\times 40$ and $\times 60$ magnifications.

Likewise, SEM images were acquired using a ZEISS SEM (model EVO 50) equipped with an Oxford Instruments dispersive X-ray spectrometer (model INCA Pentafet X3). However, because these materials are electrical insulators, they were sputtered with a $100-200 \mu \mathrm{m}$ layer of gold palladium. This task was automatically performed using an Emitech metalliser (model K550). In this case, microphotographs were taken at $\times 90$ and $\times 900$ magnifications. Both techniques were used to determine the structures of the geomembranes to assess their deterioration over time. 


\section{RESULTS AND ANALYSIS}

The results of the initial material conditions (i.e. measurements performed when the geomembranes were initially installed) indicated that, at this point, the geomembranes fully satisfied the minimum requirements established for these types of geomembranes in the Reservoirs Handbook (MARM 2010) published by CEDEX upon the request of the Spanish Ministry of Environment, Rural and Marine Affairs. The results of the previously described measurements are presented below.

Table 3. Loss of plasticisers in the geomembranes

\begin{tabular}{|l|l|l|}
\hline \multirow{2}{*}{ Reservoir } & \multicolumn{2}{|c|}{ Loss of plasticisers (\%) } \\
\cline { 2 - 3 } & \multicolumn{2}{|c|}{ Year sample was taken } \\
\cline { 2 - 3 } & 2012 & 2015 \\
\hline Hondón de las Nieves & 66.6 & 71.6 \\
El Rollo & 84.3 & 84.3 \\
Plá Aceituna & 66.4 & 70.9 \\
Caseta de Mira & 78.5 & 80.0 \\
El Cid-III & - & 78.5 \\
El Rabosero & - & 71.1 \\
\hline
\end{tabular}

Table 4. Characteristics of the Hondón de las Nieves geomembrane 25 years after installation

\begin{tabular}{|l|c|c|}
\hline \multicolumn{1}{|c|}{} & \multicolumn{2}{|c|}{ Area the samples were taken } \\
\cline { 2 - 3 } & Crest & Intermediate \\
\hline Loss of plasticiser (\%) & 71.6 & 71.4 \\
Traction resistance (N/50 mm) & 3420 & 3147 \\
$\quad$ Longitudinal & 2121 & 2425 \\
$\quad$ Transversal & 16 & 15 \\
Elongation at maximum load (\%) & 19 & 24 \\
$\quad$ Longitudinal & & \\
Transversal & 351 & 431 \\
Puncture resistance (N/mm) & 320 & 417 \\
$\quad$ External side & 7 & 8 \\
Internal side & 5 & 9 \\
Plunger displacement before perforation (mm) & \\
$\quad$ External side & 7 & \\
Internal side & & \\
\hline
\end{tabular}

\subsection{Folding at low temperature}

Based on the low temperature folding test, all the test specimens from the six reservoirs showed breakages, cracks, fissures, and other signs of surface imperfections. Initially, all the specimens passed the test.

When a homogenous geomembrane begins to have surface imperfections in this test, we observed that a re-waterproofing process should be performed in the reservoir within a few years (Crespo 2011). However, in the case of geomembranes that have been reinforced with a polyester thread fabric, that is, in this case, many years can pass before re-waterproofing is necessary.

\subsection{Plasticisers}

The loss of plasticisers in the samples taken in 2015 is shown in Table 3. The geomembrane from the reservoir Caseta de Mira has not suffered any changes since 2012. However, in other cases, a decrease of 5\% was observed.

The most significant characteristics of the samples taken from the northern slope (crest and intermediate areas) of the Hondón de las Nieves reservoir after 25 years of use are summarized in Table 4. It can be observed that while the loss of plasticisers is almost the same for both areas, the mechanical characteristics are better in the intermediate areas. Basically, the puncture resistance is higher, with higher plunger displacement values prior to perforation.

Once the plasticisers were isolated, they were identified via FTIR, which detected the bands that are listed in Table 5. It should be noted that the ester carbonyl absorption frequency is at $1720 \mathrm{~cm}^{-1}$. The characteristic ester group vibrations appear in the region of $1300-1050 \mathrm{~cm}^{-1}$. In this region, two significant absorption bands appear as a result of the symmetric and antisymmetric vibrations of the ester C-O-C group. The diverse bands clearly indicate an aromatic compound. The $740 \mathrm{~cm}^{-1}$ band clearly indicates an ortho di-substitution on the aromatic ring. The results indicate that the plasticiser is an alkyl phthalate, which was also verified by the MS results.

Figure 1 shows the MS spectrum of the plasticiser. The following fragmentations were observed: $\mathrm{MS}, \mathrm{m} / \mathrm{z}$ (relative intensity): $390\left(\mathrm{M}^{+}\right), 279\left(\mathrm{C}_{16} \mathrm{H}_{23} \mathrm{O}_{4}{ }^{+}, 12\right)$, $167\left(\mathrm{C}_{8} \mathrm{H}_{7} \mathrm{O}_{4}{ }^{+}, 39\right), 149\left(\mathrm{C}_{8} \mathrm{H}_{5} \mathrm{O}_{3}{ }^{+}, 100\right), 113\left(\mathrm{C}_{8} \mathrm{H}_{17}{ }^{+}, 9\right)$, and $57\left(\mathrm{C}_{4} \mathrm{H}_{9}{ }^{+}, 18\right)$. This was identified as the bis(2-ethylhexyl) phthalate. Its molecular weight is 390 ,

Table 5. Main FTIR bands for the PVC-P plasticisers

\begin{tabular}{|l|l|l|}
\hline Wavenumber $\left(\mathrm{cm}^{-1}\right)$ & Chemical group & Bands \\
\hline 3080 & $\mathrm{H}-\mathrm{C}=$ & Stretching vibration (in aromatics) \\
$2965-2870$ & $\mathrm{H}-\mathrm{C}$ & Stretching vibrations (methyl and alkyl groups) \\
1720 & $\mathrm{C}=\mathrm{O}$ & Stretching vibration (carbonyl group) \\
$1600-1585$ & $\mathrm{C}=\mathrm{C}$ & Skeletal vibrations (ring stretch) \\
1460 & $\mathrm{C}=\mathrm{C}$ & Skeletal vibrations (ring stretch) \\
1455 & $\mathrm{CH}_{2}$ & Scissoring deformation \\
1375 & $\mathrm{CH}_{3}$ & Symmetrical bending \\
$1300-1075$ & $\mathrm{C}-\mathrm{O}-\mathrm{C}$ & Symmetrical and asymmetrical stretching \\
740 & $\mathrm{C}-\mathrm{H}$ & Out of plain ring bending vibrations \\
720 & $\mathrm{CH}$ for $\left(\mathrm{CH}_{2}\right)_{\mathrm{n}}$ with $n \geq 4$ & Rocking vibration \\
\hline
\end{tabular}




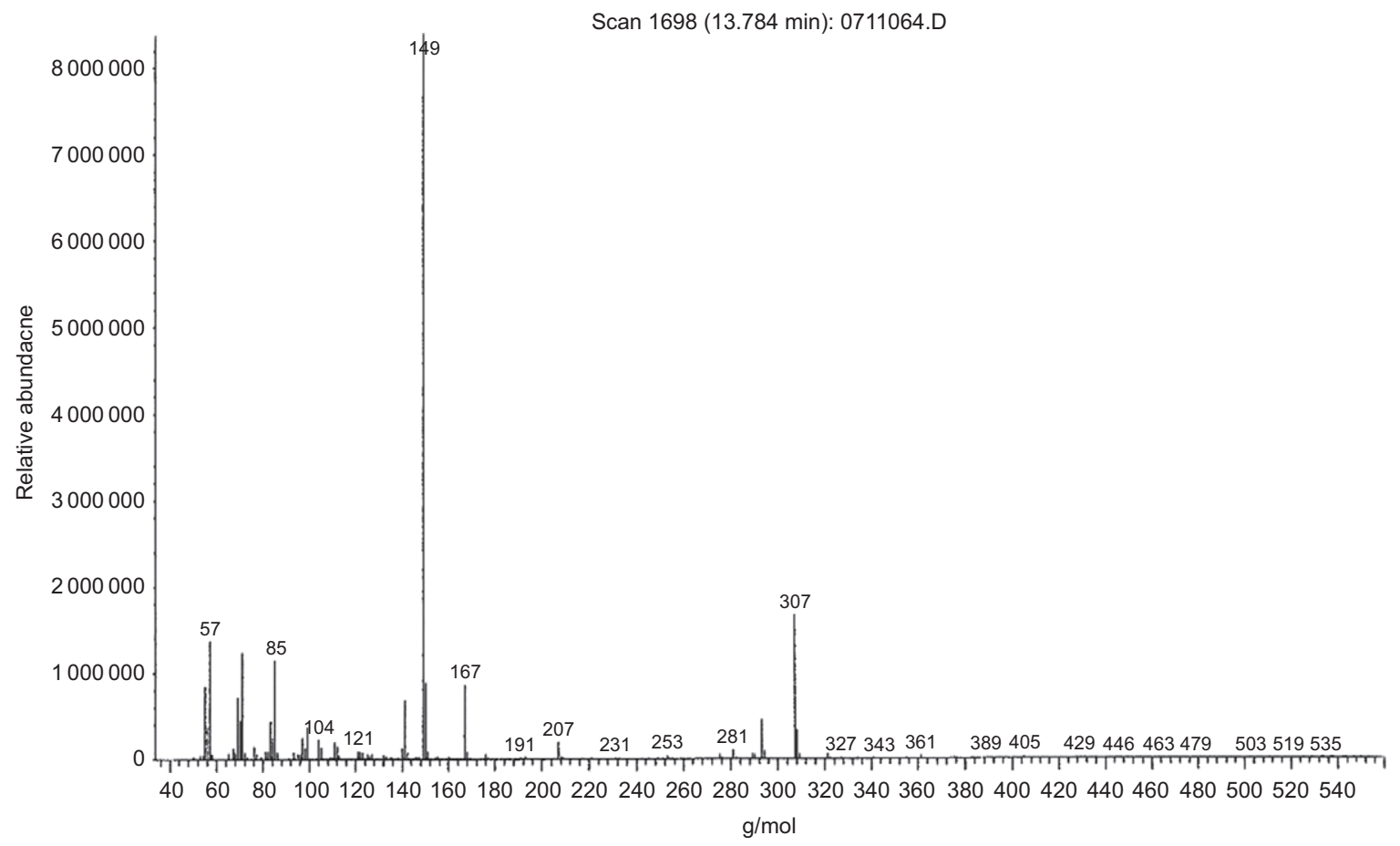

Figure 1. Mass spectrum of the plasticiser extracted from the geomembrane

which is lower than the current recommended value of 400 for high-durability PVC-P geomembranes (PGI 2004; MARM 2010).

The low molecular weight of this additive justifies its tendency to fundamentally migrate to the air (Stark et al. 2005). Additionally, this behaviour is consistent with the high losses of plasticisers found in all the geomembranes. GC showed a chromatogram with a single peak at a 82.93 min retention time.

When the PVC-P geomembranes were installed, and even a decade after their installation, bis(2-ethylhexyl) phthalate was the most widely used plasticiser. However, it has since ceased to be used as a unique plasticiser. Currently, plasticisers with the alkyl radicals that contain 10 and 12 carbon atoms are typically used. The higher molecular weights of these plasticisers result in slower migration, and they are more environmentally friendly.

\subsection{Dynamic impact}

All the test specimens passed the dynamic impact test. Cracks, fissures, or other signs of deterioration were not observed in the impact area after the test device was dropped from a height of $500 \mathrm{~mm}$. Despite the high degree of plasticiser loss, the geomembranes could still withstand the dynamic impact action. This highlights the good condition of the textiles reinforced with fabrics.

\subsection{Puncture resistance}

The puncture resistance and plunger displacement prior to perforation values are summarized in Table 6. It can be observed that the plunger displacement values are relatively low, and only the membranes from El Rollo would initially pass the Spanish standards for newer geomembranes in the Reservoirs Handbook (MARM 2010).

Table 6. PVC-P geomembrane mechanical and puncture characteristics

\begin{tabular}{|c|c|c|c|c|c|c|}
\hline & \multicolumn{6}{|c|}{ Reservoir } \\
\hline & Hondón de las Nieves & Plá Aceituna & El Rollo & Caseta de Mira & El Cid-III & El Rabosero \\
\hline \multicolumn{7}{|c|}{ Traction resistance $(\mathrm{N} / 50 \mathrm{~mm})$} \\
\hline Longitudinal & 3420 & 3214 & 3919 & 2888 & 2470 & 2999 \\
\hline Transversal & 2121 & 2333 & 3977 & 1943 & 902 & 3145 \\
\hline \multicolumn{7}{|c|}{ Elongation at maximum load (\%) } \\
\hline Longitudinal & 16 & 23 & 18 & 21 & 14 & 20 \\
\hline Transverse & 19 & 25 & 34 & 24 & 10 & 33 \\
\hline \multicolumn{7}{|c|}{ Puncture resistance $(\mathrm{N} / \mathrm{mm})$} \\
\hline External side & 351 & 472 & 829 & 499 & 560 & 445 \\
\hline Internal side & 320 & 433 & 812 & 386 & 378 & 318 \\
\hline \multicolumn{7}{|c|}{ Plunger displacement before perforation (mm) } \\
\hline External side & $7+1=1$ & 5 & 12 & 8 & 11 & 4 \\
\hline Internal side & 5 & 5 & 12 & 7 & 8 & 3 \\
\hline
\end{tabular}


It is noteworthy to mention that the reinforcement used in the geomembranes also initially showed low puncture resistance values.

\subsection{Tensile characteristics}

The tensile values for the samples are shown in Table 6 . Only the geomembrane from the El Cid-III reservoir showed low values for both the load and elongation, which agreed with its older installation age (31 years). The membrane has already lost part of the resin covering the reinforced polyester, and the textile is directly exposed to UV radiation, which further degrades it and leads to a reduction in both the load and elongation.

Even in the initial geomembranes, the textile reinforcement showed a high tensile behavior, with values higher than $2200 \mathrm{~N} / 50 \mathrm{~mm}$, which easily fulfilled the minimum Spanish requirements $(1100 \mathrm{~N} / 50 \mathrm{~mm})$. However, these values have increased over time due to the higher rigidity of the sheets and the loss of plasticisers.

\subsection{Seam resistance}

The seam resistance values observed from the tension procedure are shown in Table 7. The obtained values are relatively high because of the reinforcement textile. All of the values surpass $2000 \mathrm{~N} / 50 \mathrm{~mm}$, with the exception of those from the El Cid-III and El Rollo reservoirs, which have the oldest installation age (1980).

The peeling method resistance test was only performed for the El Rabosero reservoir because of the joining between the panels. The geomembrane from this reservoir provided a moderately acceptable value of $302 \mathrm{~N} / 50 \mathrm{~mm}$ considering its long installation time (21 years).

Table 7. Joint shear resistance

\begin{tabular}{|l|c|}
\hline Reservoir & Joint shear resistance $(\mathrm{N} / 50 \mathrm{~mm})$ \\
\hline Hondón de las Nieves & 2178 \\
El Rollo & 1119 \\
Plá Aceituna & 2062 \\
Caseta de Mira & 2036 \\
El Cid-III & 1651 \\
El Rabosero & 2593 \\
\hline
\end{tabular}

\subsection{ROM and SEM}

The original samples observed using SEM at $\times 90$ and $\times 900$ magnifications are shown in Figures 2 and 3, respectively. In the first image $(\times 90)$, the presence of micropores can be observed, and they are clearly evident in the second microphotograph taken at a higher magnification $(\times 900)$.

For all the 2015 samples, Figure 4 depicts the ROM images for the external side at $\times 60$ magnification. Likewise, Figure 5 shows the appearance of the external side of the materials by SEM at $\times 90$ magnification. Both the ROM and SEM images reveal a significant deterioration in the external side of the geomembranes, with visual evidence of surface cracking.

For the samples exhumed from the El Cid-III reservoir 31 years after installation, the microscopy images of the internal side show good material conditions (Figure 6). The comparison between the two sides of the test specimens illustrates the effect of UV radiation on the deterioration of the organic material.

Finally, Figure 7 shows a set of SEM $(\times 90)$ microphotographs of the geomembrane from the northern slope (south facing) of the Hondón de las Nieves reservoir. The microphotographs in the upper part correspond to the crest area of the reservoir, which is where the geomembrane was always in contact with solar radiation. The microphotographs in the lower part were taken of the membrane from the intermediate area, which is where the geomembrane was exposed to weathering and covered by water.

The external side shows notable cracking, which was slightly greater in the crest sample, and for the internal side, some craters can be observed. Possibly, these craters are related to the micropores that were initially observed in the geomembrane and are a consequence of the impregnation process used in the manufacturing. The coalescence of these pores and material ageing cause the formation of craters and cracking over time.

\section{GEOMEMBRANE END OF LIFE}

The durability of geomembranes depends on intrinsic factors, such as their composition and thickness, and extrinsic

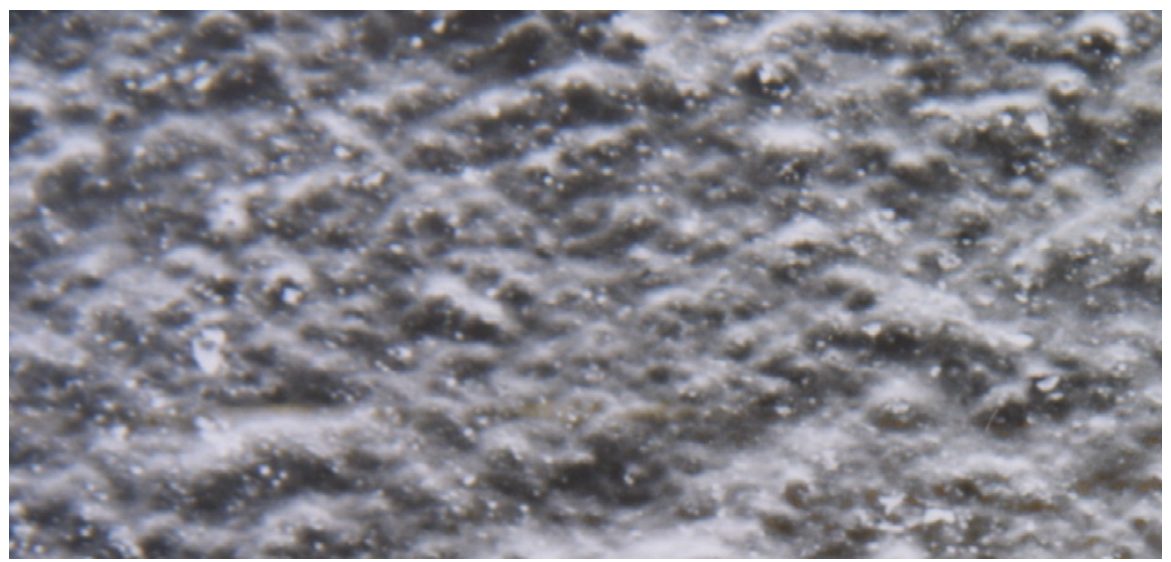

Figure 2. SEM microphotograph of the original geomembrane at $\times 90$ magnification 


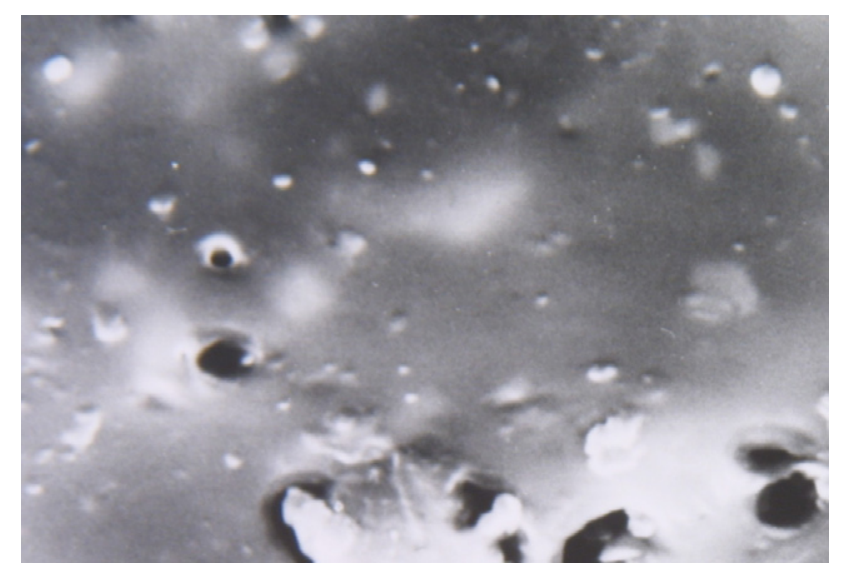

Figure 3. SEM microphotograph of the original geomembrane at $\times 900$ magnification factors, such as stresses and different environmental agents (Cazzuffi 2014). The latter will affect all types of geomembranes, irrespective of the nature of the resin. A photo- and thermal oxidation process will produce a series of free radicals that cause a haemolytic chain reaction, which deteriorates the macromolecule. However, some intrinsic factors are specific to each geomembrane.

The lifetime of a geomembrane can be assessed via the evolution of one or several fundamental characteristics, depending on the nature of the geomembrane (Noval 2015b). Different authors have proposed that the service life of a geomembrane comes to an end when this fundamental characteristic loses $50 \%$ of its value. However, this value is not defined. The scientific literature considers two possibilities, which can be defined as

- Theory A. The service life ends when the fundamental characteristic under consideration has lost 50\% of its original value (Hsuan and Koerner 1998).

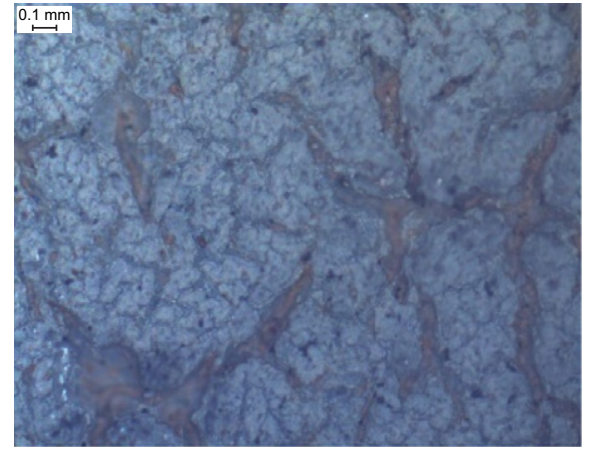

(a)

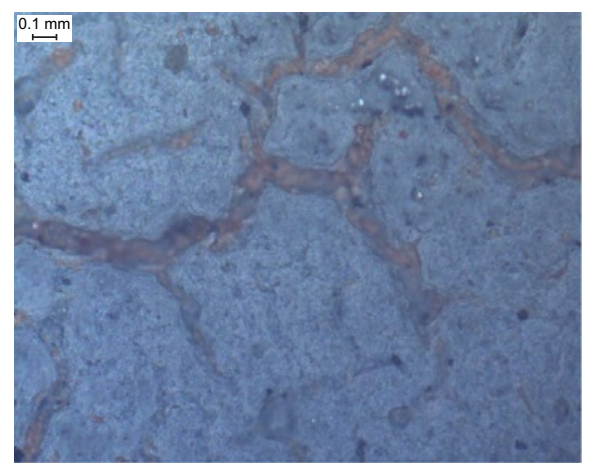

(c)

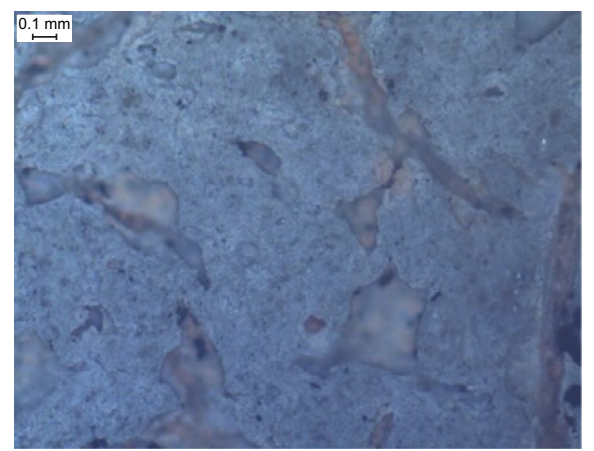

(e)

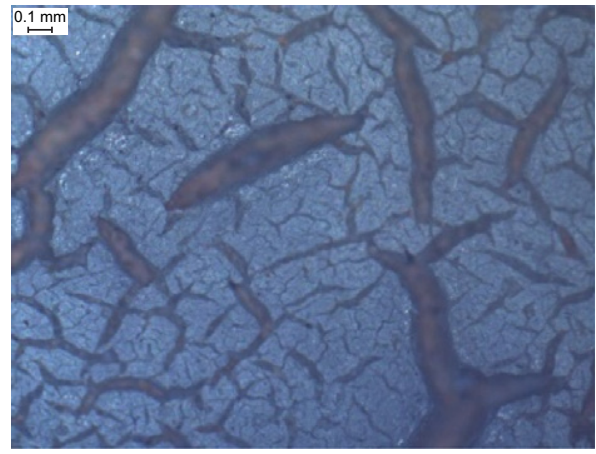

(b)

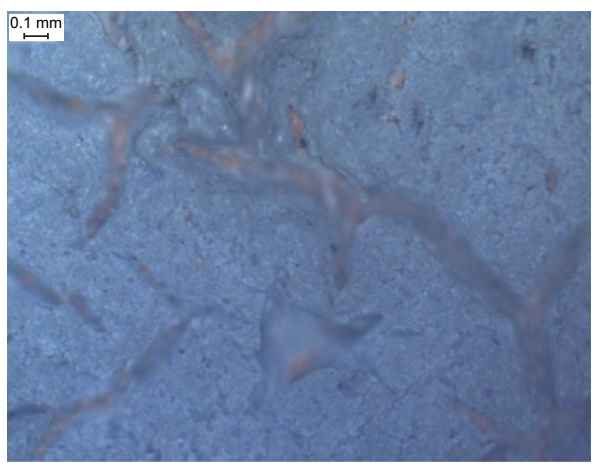

(d)

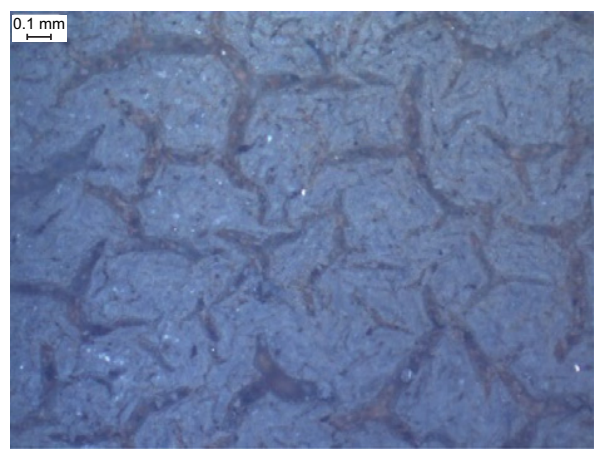

(f)

Figure 4. ROM microphotographs of the external sides at ×60 magnification. (a) Hondón de las Nieves; (b) Plá Aceituna; (c) El Rollo; (d) Caseta de Mira; (e) EI Cid-III; (f) EI Rabosero 


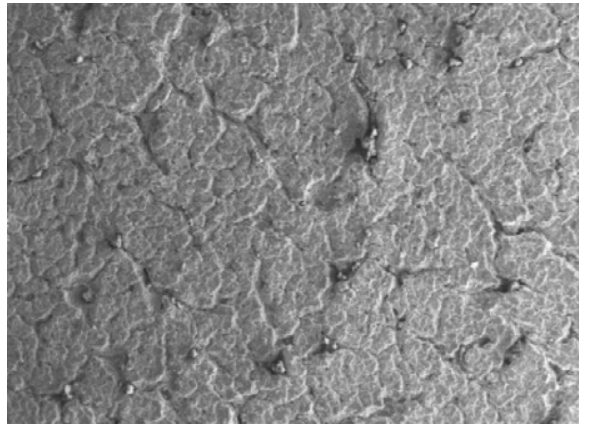

(a)

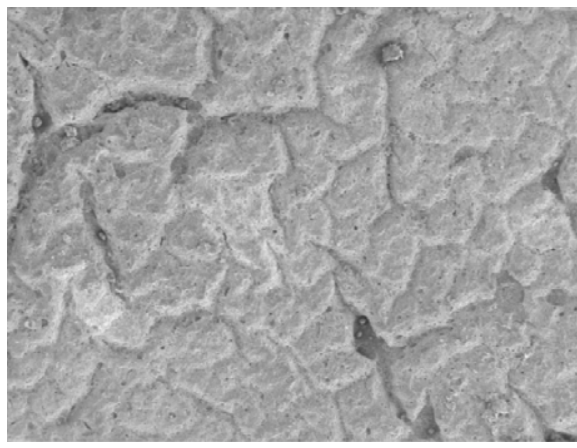

(c)

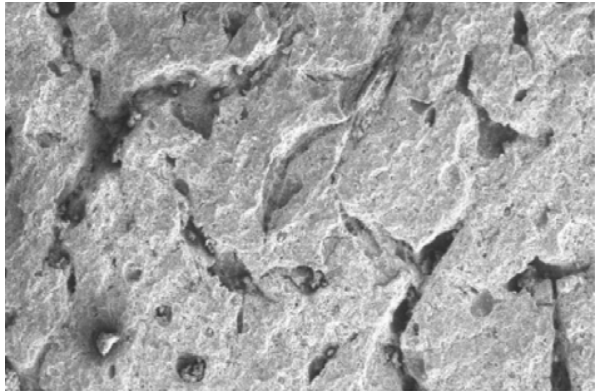

(e)

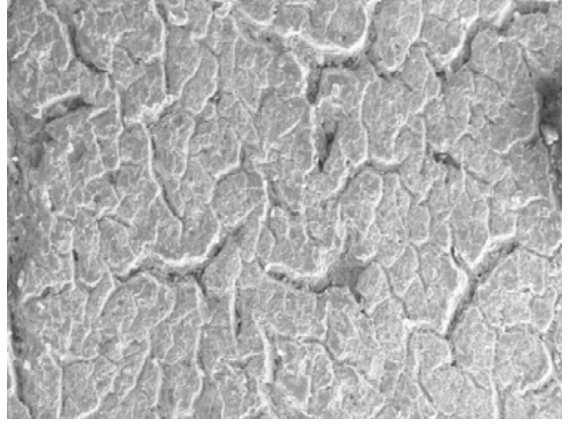

(b)

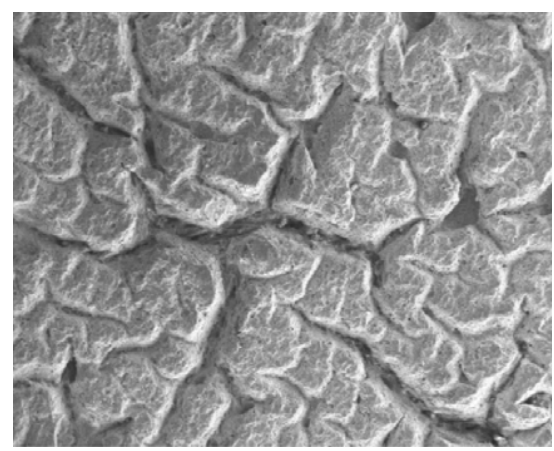

(d)

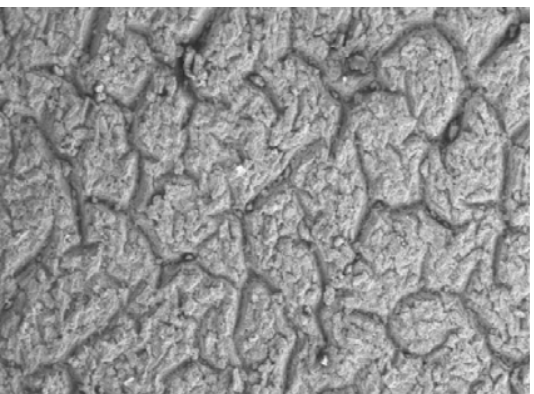

(f)

Figure 5. SEM microphotographs of the external side of the geomembranes at $\times 90$ magnification. (a) Hondón de las Nieves; (b) Plá Aceituna; (c) El Rollo; (d) Caseta de Mira; (e) El Cid-III; (f) El Rabosero

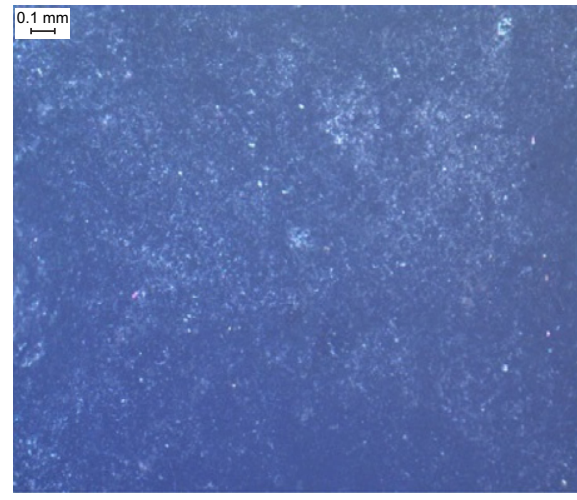

(a)

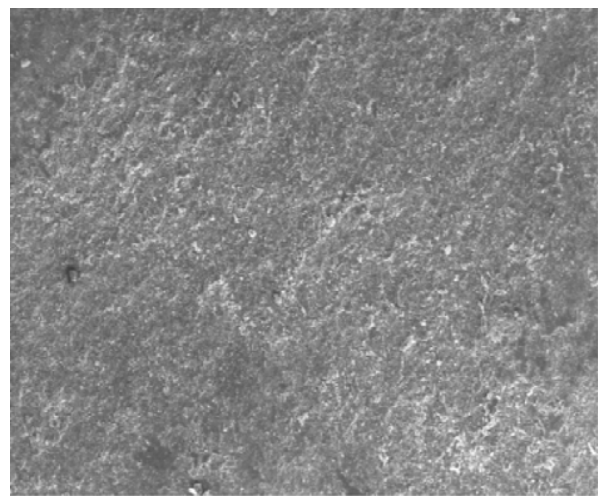

(b)

Figure 6. (a) ROM and (b) SEM microphotographs of the internal side of samples from the EI Cid III reservoir at $\times 60$ and $\times 90$ magnification, respectively

- Theory B. The service life ends when the fundamental characteristic under consideration has lost 50\% of the value required by current regulations (Rowe et al. 2009).
The above theories refer to HDPE geomembranes. Regarding the key parameter under consideration, different international forums refer to stress cracking and oxidation induction times. However, some authors 


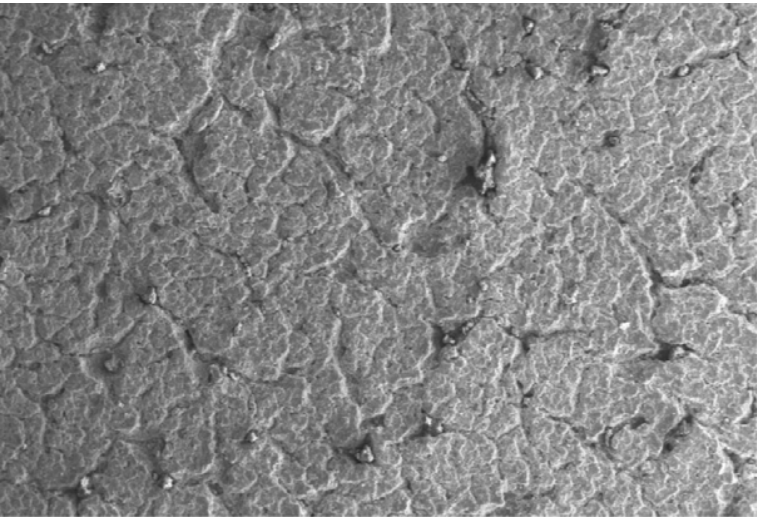

(a)

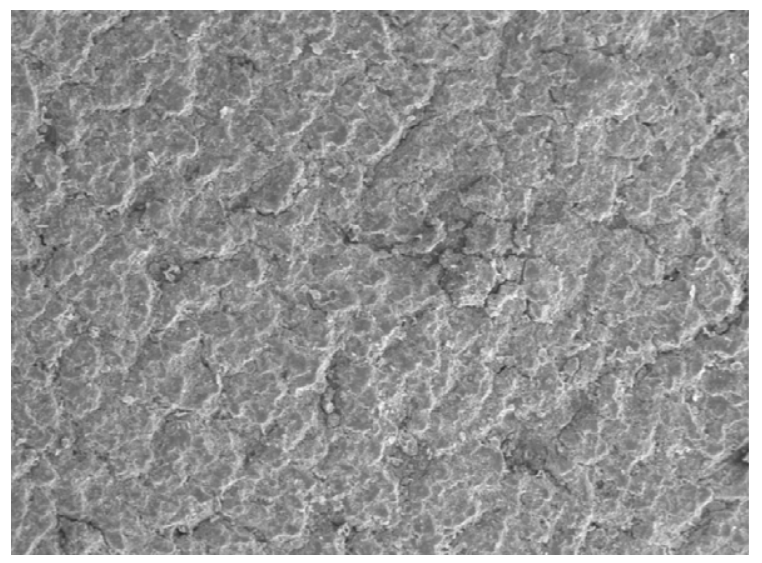

(c)

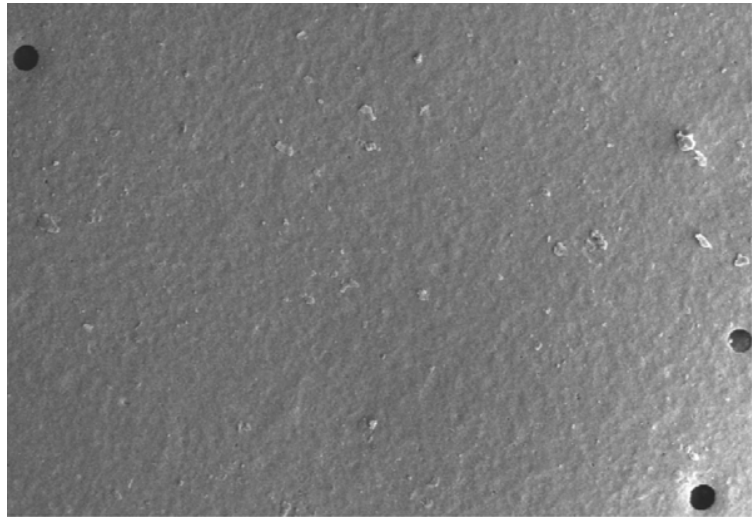

(b)

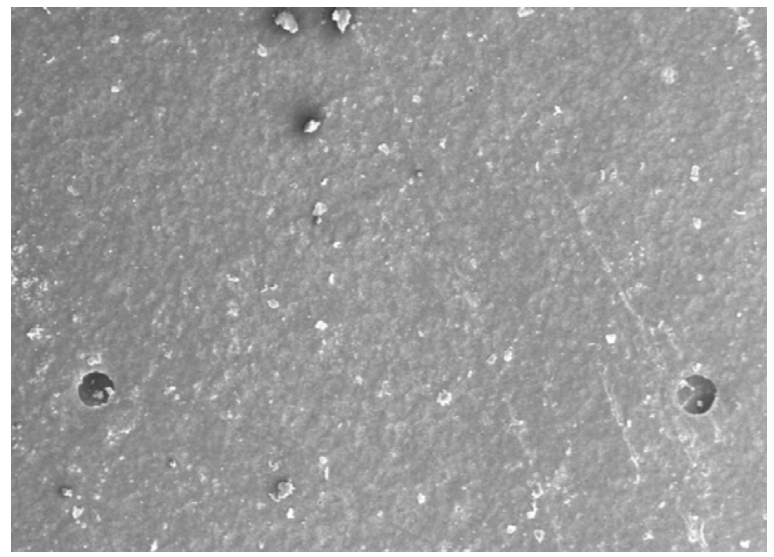

(d)

Figure 7. SEM microphotographs of the geomembrane from Hondón de las Nieves reservoir at $\times 90$ magnification. (a) External side at crest, (b) internal side at crest, (c) external side in the intermediate area, (d) internal side in the intermediate area

reference the carbonyl index and durability factor, which is defined as the coefficient between stress cracking and the carbonyl index (Blanco 2015).

Based on this approach, we extended these theories to other types of geomembranes. EPDM geomembranes have been successfully evaluated using the elongation at break, since this fundamental characteristic significantly decreases over time as the polymer vulcanisation increases (Blanco 2015; Noval 2015a).

For PVC-P, in addition to the folding at low temperature, we also considered the loss of plasticisers. Our field experience, based on periodic monitoring of more than two-hundred exposed hydraulic structures throughout Spain, indicates that when the folding begins to fail, the geomembrane service life is nearing the end. The geomembrane may last a few more years depending on the geographic location of the structure and the mechanical requirements of the reservoir, but overall, the integrity of the material is severely damaged (Blanco et al. 2003b, 2012). In contrast, the reservoirs studied in this research showed significant durability levels although the samples broke in the folding test. The polyester-reinforced textile contributes to the better performance of the geomembranes, and additional key characteristics should be considered in the durability assessment. Thus, the loss of plasticisers was also considered in the PVC-P weathering approach.
Table 8. PVC-P values of the main characteristics after losing $50 \%$ of their original values according to Theory A \& B

\begin{tabular}{|l|c|c|}
\hline Characteristic & Theory A & Theory B \\
\hline \begin{tabular}{l|c} 
Plasticiser content (\%) \\
Traction resistance (N/50 mm)
\end{tabular} & 17.1 & - \\
$\quad$ Longitudinal & 1104 & 550 \\
$\quad$ Transverse & 1102 & 550 \\
Elongation at maximum load (\%) & 9 & 8 \\
$\quad$ Longitudinal & 17 & 8 \\
$\quad$ Transversal & 266 & - \\
Puncture resistance (N/mm) & 225 & - \\
$\quad$ External side & 4 & 6 \\
Internal side & 3 & 6 \\
Plunger displacement before perforation (mm) & \\
$\quad$ External side & & \\
Internal side &
\end{tabular}

The values for the most important characteristics of the PVC-P geomembranes for both theories are summarized in Table 8. These technical requirements are fully described in the Spanish Reservoirs Handbook (MARM 2010). In theory B, the plasticiser content is not considered a fundamental requirement because any manufacturer can change rigid PVC into flexible PVC using different methods, including internal plasticisation. Additionally, the puncture resistance results for theory B (Table 8) only consider the data from the plunger 
displacement prior to perforation, since this characteristic best defines the puncture behaviour (MARM 2010). All the geomembranes studied surpass the minimum required values for both theories. However, as shown in Table 3, all the tested geomembranes have suffered a loss of plasticiser that is far higher than $50 \%$ of its original content.

The straightforward application of the above theories for an exposed PVC-P geomembrane installed in an irrigation reservoir is too restrictive. As mentioned above, the authors have assessed and monitored different geomembranes in Spain that do not meet the requirements of the aforementioned theories over time. However, the geomembranes continue to fulfil their waterproofing purpose. For PVC-P, several cases support this conclusion since more than $50 \%$ of the additive was lost but the geomembrane has not yet been removed. Moreover, some PVC-P geomembranes installed in Spain exhibited losses higher than $80 \%$, but they still fulfil their working requirements in the reservoirs (Blanco et al. 2013b; Noval et al. 2014c). Nonetheless, it is important to stress that these geomembranes are reinforced with a synthetic thread textile.

\section{CONCLUSIONS}

The work reported in this paper is based on studying exposed PVC liners in the southeast of Spain and installed according to European practice. The applications, design practice, materials and performance may not apply to other regions and jurisdictions.

The tests carried out on the original geomembranes verified that they fully satisfied the Spanish regulations in force for a PVC-P geomembrane at the time of their installation. Accordingly, the mechanical characteristics of these materials are excellent, and they have remained well preserved over time. The tension resistances of the geomembranes are very high; that is, double the minimum values required by regulations for this type of geomembrane, except for the geomembrane installed 31 years ago. This is due to the geotextile reinforcement. The results, based on the location the samples were exhumed from in the reservoirs, show that the samples from the intermediate area have a better mechanical performance, but the differences were not significant. Regarding the hydraulic working performance of these waterproofed reservoirs, water leakage over time through the drainage monitoring system has not been observed.

The data obtained in the microscopic analysis show geomembranes with internal sides that are in good condition with isolated craters; however, the external sides show a high level of deterioration and surface cracking.

The plasticiser was identified after extraction with ethyl ether using FTIR, GC and MS, and it was bis(2-ethylhexyl) phthalate, which has a low molecular weight of 390 and a branched alkyl radical that promotes air migration. The alkyl radical substitutes the phthalic acid protons, leading to a significant loss of this additive.

The high durability of these geomembranes is due to the behaviour of the reinforcement polyester textile.
The reinforced textile is still covered with vinyl resin, which prevents solar radiation exposure.

The durability assessment of the geomembranes is based on the loss of fundamental characteristics. The plasticiser content was the key parameter analysed. The results revealed that the loss of plasticisers was greater than $70 \%$ in all cases and reached $84 \%$ in one sample. Therefore, the loss of plasticisers is significantly greater than the 50\% threshold referred to in scientific recommendations, but all the geomembranes still provide containment.

In conclusion, the geomembranes are still installed in reservoirs and still fulfil their waterproofing function, which implies that the current loss of plasticisers durability criteria needs to be further discussed based on the extra field reservoir data.

\section{ACKNOWLEDGEMENTS}

The authors wish to express their gratitude to R. A. de las Revillas and P. Iglesias of the Universidad Complutense in Madrid for their help with the analysis and to G. Calleja (CEDEX) for help with the microscopy studies.

\section{ABBREVIATIONS}

$\begin{aligned} \text { AENOR } & \text { Asociación Española de Normalización y } \\ & \text { Certificación } \\ \text { BALTEN } & \text { Balsas de Tenerife } \\ \text { CEDEX } & \text { Centro de Estudios y Experimentación de } \\ & \text { Obras Públicas } \\ \text { CPE } & \text { Chlorinated polyethylene } \\ \text { EN } & \text { European Norm } \\ \text { EPDM } & \text { Ethylene-propylene-diene terpolymer } \\ \text { FTIR } & \text { Fourier transform infrared spectroscopy } \\ \text { GC } & \text { Gas chromatography } \\ \text { HDPE } & \text { High density polyethylene } \\ \text { ICOLD } & \text { International Commission on Large Dams } \\ \text { IIR } & \text { Butyl rubber } \\ \text { LDPE } & \text { Low density polyethylene } \\ \text { MARM } & \text { Ministerio de Medio Ambiente y Medio } \\ & \text { Rural y Marino } \\ \text { MS } & \text { Mass spectrometry } \\ \text { PIB } & \text { Polyisobutylene } \\ \text { PVC-P } & \text { Plasticised poly(vinyl chloride) } \\ \text { ROM } & \text { Reflection optical microscopy } \\ \text { SEM } & \text { Scanning electron microscopy } \\ \text { UNE } & \text { Spanish Standard } \\ \text { UV } & \text { Ultraviolet }\end{aligned}$

\section{REFERENCES}

AENOR (Asociación Española de Normalización y Certificación) (1981). UNE 53 095. Plásticos. Determinación de la migración de los plastificantes. Anulada y sustituida por la UNE-EN ISO 77:2001. AENOR, Madrid, Spain (in Spanish).

AENOR (1990). UNE 53 028. Materiales plásticos. Determinación de la absorción de agua. Anulada y sustituida por la UNE-EN ISO 62:2008. AENOR, Madrid, Spain (in Spanish). 
AENOR (1996). UNE EN ISO 527-3. Plásticos. Determinación de las características de tracción. Parte 3: Condiciones de ensayo para películas y láminas. AENOR, Madrid, Spain (in Spanish).

AENOR (2000). UNE 104 306. Materiales sintéticos. Determinación del contenido en plastificantes en láminas de poli (cloruro de vinilo) plastificado, PVC-P, utilizadas en impermeabilización. AENOR, Madrid, Spain (in Spanish)

AENOR (2011). UNE 104 317. Materiales sintéticos. Determinación del recorrido del punzón antes de la perforación en geomembranas sintéticas impermeabilizantes instaladas en balsas. AENOR, Madrid, Spain (in Spanish).

AENOR (2013a). EN 13 361. Barreras geosintéticas. Características para su utilización en la construcción de embalses y presas. AENOR, Madrid, Spain (in Spanish)

AENOR (2013b). EN 495-5. Láminas flexibles para impermeabilización. Determinación del doblado a bajas temperaturas. Parte 5: Láminas de plástico y caucho para impermeabilización de cubiertas. AENOR, Madrid, Spain (in Spanish)

Aguiar, E. \& Blanco, M. (1995). Experience in connection with the performance of plasticized polyvinyl chloride sheeting in Tenerife basin sealing. Proc. Symposium ICOLD on Research and Development in the Field of Dams, Crans-Montana, Suiss.

Aguiar, E., Blanco, M., Soriano, J. \& Vara, T. (2003). Influencia de la orientación en la degradación del poli(cloruro de vinilo) plastificado utilizado como geomembrana sintética en la impermeabilización del embalse de La Tabona. Ing. Civil, 130, No. 1, 95-103 (in Spanish).

Amigó, E. \& Aguiar, E. (1994). Manual para el diseño, construcción y explotación de embalses impermeabilizados con geomembranas, Consejería de Agricultura y Alimentación. Gobierno de Canarias, Islas Canarias, Spain (in Spanish).

ASTM (2011) D2124-99: Standard Test Method for Analysis of Components in Poly(Vinyl Chloride) Compounds Using an Infrared Spectrophotometric Technique. ASTM International, West Conshohocken, PA, USA.

Blanco, M. (2005). Geomembranas I. Proc. I Simposio Nacional sobre proyecto, construcción e impermeabilización. IGS-Spain, Sevilla, Spain (in Spanish).

Blanco, M. (2015). Las geomembranas sintéticas poliméricas en la impermeabilización de obras hidráulicas. Keynote Lecture. Geosintec 2, IGS-Spain, Madrid, Spain, pp. 15-31 (in Spanish).

Blanco, M. \& Aguiar, E. (1993). Comportamiento de láminas de poli (cloruro de vinilo) plastificado, utilizadas en la impermeabilización de balsas en el norte de Tenerife. Ing. Civil, 88, No. 2, 5-20 (in Spanish).

Blanco, M. \& Zaragoza, G. (2003). El Odiel-Perejil como un caso pionero en la utilización de una geomembrana sintética en la impermeabilización de presas. Ing. Civil, 132, No. 1, 33-40 (in Spanish).

Blanco, M., Cuevas, A. \& Ortega, J. J. (1989). Espectros de infrarrojo de los distintos tipos de resinas utilizadas en la formulación de pinturas. Pub. CEDEX. Cuadernos de Investigación C-19, Cedex, Madrid, Spain, pp. 51-79 (in Spanish).

Blanco, M., Cuevas, A., Castillo, F. \& Aguiar, E. (1996). Puesta a punto de una nueva metodología experimental para la determinación de la resistencia a la perforación de geomembranas sintéticas. Ing. Civil, 103, No. 1, 65-69, (in Spanish).

Blanco, M., Soriano, J., Aguiar, E. \& Zaragoza, G. (2002). Análisis microscópico de geomembranas sintéticas utilizadas en la impermeabilización de embalses. Ing. Civil, 127, No. 1, 51-59 (in Spanish).

Blanco, M., Zaragoza, G. \& Aguiar, E. (2003a). El seguimiento de geomembranas sintéticas como factor que contribuye a la seguridad y durabilidad de la impermeabilización de embalses. Ing. Civil, 129, No. 2, 53-70 (in Spanish).

Blanco, M., Leiro, A., Soriano, J., Aguiar, E., Armendáriz, V. \& Vara, T. (2003b). Influencia de la orientación en el deterioro de la geomembrana sintética utilizada como pantalla de impermeabilización en el embalse de la Cruz Santa. Proc. VII Congreso Latinoamericano de Patología de la Construcción. ALCONPAT, Mérida, Yucatán, Mexico (in Spanish)
Blanco, M., Rico, G., Pargada, L., Castillo, F. \& Aguiar, E. (2008). Estudio de plastificantes utilizados en geomembranas de PVC-P empleadas en impermeabilización de obras hidráulicas. Rev. Plast. Modernos, 96, No. 629, 386-391 (in Spanish).

Blanco, M., Rico, G., Pargada, L., Aguiar, E. \& Castillo, F. (2009). Determinación de los ftalatos utilizados como aditivos en la geomembrana de la balsa de La Florida mediante cromatografía de gases-espectrometría de masas. Ing. Civil, 154(1), 87-95 (in Spanish).

Blanco, M., Castillo, F., García, F. \& Soriano, J. (2010). Las geomembranas sintéticas en la rehabilitación y mantenimiento de paramentos de presas. Dam Maintenance and Rehabilitation II, García RR, Mir MA, Bitrián FH et al., Editors, Taylor \& Francis Group, London, UK, pp. 335-341 (in Spanish).

Blanco, M., Castillo, F., García, F., Mateo, B., Solera, R., García, C., de Cea, J. C. \& García-Wolfrum, S. (2012). Monitoring of synthetic geomembranes used for waterproofing in hydraulic works. In Eurogeo5, Vol. 2: 64-69 (Electronic Proceedings) Vol. 1: 274-279 (Printed Volumes) Blanco M, Leiro A, Torregrosa JB et al., Editors, Ed. R. B. Servicios Editoriales, S. L, Valencia, Spain, pp. 64-69.

Blanco, M., Crespo, M. A., Leiro, A. \& Mateo, B. (2013a). Relación entre la durabilidad de geomembranas de PVC-P y el tipo de plastificante utilizado como aditivo. Proc. XII Congreso Latinoamericano de Patología de la Construcción y XIV Congreso de Control de Calidad de la Construcción CONPAT-Colombia, Cartagena de Indias. ALCONPAT, Cartagena de Indias, Colombia vol. P, pp. 583-592 (in Spanish).

Blanco, M., Noval, A. M., García, C., Aguiar, E., Vara, T., Ferrán, J. J., Ferrer, C. M., Pérez, M., Redón, M., Sánchez, F. J., Torregrosa, J. B. \& Zapata, F. A. (2013b). Descripción del comportamiento de diferentes geomembranas de PVC-P instaladas en balsas hace más de veinte años. Proc. Congreso Geosintec Iberia 1. IGS-Spain, Sevilla, Spain, pp. 179-184 (in Spanish).

Blanco, M., Castillo, F., Touze-Foltz, N., Amat, B. \& Aguiar, E. (2015). Behaviour of an EPDM geomembrane 18 years after its installation in a water reservoir. International Journal of Geomate, 9, No. 1, $1348-1352$.

Blanco, M., Noval, A. M., Mateo, B., Aguiar, E., Vara, T., Touze-Foltz, N. \& Farcas, F. (2016a). Performance of geomembranes seldom used in hydraulic works, installed in the experimental field of El Saltadero. Eurogeo6. IGS-Turkey, Ljubljana, Slovenia, pp. 440-449.

Blanco, M., Solera, R., Giroud, J. P., Pérez Sánchez, M., Redón Santafé, M., Sánchez Romero, F. J., Torregrosa Soler, J. B. \& Zapata Raboso, F. A. (2016b). Characteristics of six PVC-P geomembranes installed in reservoirs in Spanish Mediterranean Basin. Eurogeo6. IGS-Turkey, Ljubljana, Slovenia, pp. 623-631.

Cazzuffi, D. (1987). The use of geomembranes in Italian dams. International Water Power \& Dams Construction, 39, No. 3, 17-21.

Cazzuffi, D. (2013). Long-time behaviour of exposed geomembrane used for the upstream face rehabilitation of concrete and masonry dams. Geosintec 1. IGS-Spain, Sevilla, Spain, pp. 26-36.

Cazzuffi, D. (2014). Long-time performance of exposed geomembranes used for the upstream face rehabilitation of dams in Northern Italy. 10th International Conference on Geosynthetics, IGS (Germany) - German Geotechnical Society, Berlin, Germany, pp. 100-112.

Cazzuffi, D., Giroud, J. P., Scuero, A. \& Vaschetti, G. (2010). Geomembranes in dams: wordwilde applications and long-term behaviour. Keynote Lecture Proceedings of the 9th International Conference on Geosynthetics. IGS-Brasil, Guaruja, Brasil, vol. I, pp. $115-163$.

Crespo, M. A. (2011). Comportamiento de barreras geosintéticas poliméricas (GBR-P) a base de poli(cloruro de vinilo) plastificado de distinta formulación, instaladas en embalses, Tesis doctoral, Universidad Complutense de Madrid, Madrid, Spain (in Spanish).

de Cea, J. C., Asanza, E. \& Blanco, M. (2003). Face protection: geomembranes lining vs. paint coating. Proceedings 21st International Congress on Large Dams, ICOLD, Montreal, Canada, pp. 582-593. 
Giroud, J. P. (1995). Evaluation of PVC geomembrane shrinkage due to plasticizer loss. Geosynthetics International, 2, No. 6, 1099-1113.

Hsuan, Y. G. \& Koerner, R. M. (1998). Antioxidant depletion lifetime in high density polyethylene geomembranes. Journal of Geotechnical and Geoenvironmental Engineering, 124, No. 6, 532-541.

ICOLD (International Commission on Large Dams) (1991). Watertight geomembranes for dams. State of the art, ICOLD Bulletin No 78, Paris, France, p. 130.

ICOLD (2010). Geomembrane sealing systems for dams. Design principles and review of experience. ICOLD Bulletin No 135 , Paris, France, p. 464.

Koerner, R. M., Hsuan, Y. G. \& Koerner, G. R. (2005). GRI White Paper 6 on Geomembrane Lifetime Prediction: Unexposed and Exposed Conditions. Geosynthetic Institute, Folson, PA, USA.

MARM (Ministerio de Medio Ambiente, y Medio Rural y Marino) (2010). Manual de diseño, construcción, explotación y mantenimiento de balsas, CEDEX, MARM, Madrid, Spain, (in Spanish)

Méndez, C., González, J. M., Zapata, F. A. \& Gómez-Nieves, A. (2008). Reimpermeabilización de balsas de riego en la provincia de Alicante. Cinco casos particulares. Proc. $2^{\circ}$ Congreso Nacional de Impermeabilización: Edificación y Obra Pública y $2^{\circ}$ Congreso Internacional sobre proyecto, construcción e impermeabilización de balsas, IGS-Spain, Palma de Mallorca, Spain, pp. 737-748 (in Spanish).

Noval, A. M. (2015a). Estudio del comportamiento de tres geomembranas de EPDM, PVC-P y PEAD a lo largo del tiempo, Tesis doctoral, Universidad Carlos III, Madrid, Spain (in Spanish).

Noval, A. M. (2015b). Durabilidad de tres geomembranas de distinta naturaleza (PVC-P, PEAD, EPDM) empleadas en la impermeabilización de embalses. Geosintec 2, IGS-SPAIN, Madrid, Spain, pp. 40-51.

Noval, A. M., Blanco, M., Castillo, F., Leiro, A. Mateo, B., Zornberg, J. G., Aguiar, E., Torregrosa, J. B. \& Redón, M. (2014a). Long-term performance of the HDPE geomembrane at the 'San Isidro' reservoir. 10th International Conference on Geosynthetics, IGS (Germany) - German Geotechnical Society, Berlin, Germany, pp. $427-440$.

Noval, A. M., Blanco, M., Farcas, F. \& Touze-Foltz, N. (2014b). End of life of HDPE geomembranes used to waterproofing reservoirs. Geomembrane Workshop Berlin-2: Developing a Protocol to Determine the Remaining Service Life of Installed Exposed HDPE Geomembranes, BAM, Germany's Federal Institute for Materials Research and Testing, Berlin, Germany, pp. 142-157.
Noval, A. M., Blanco, M., Farcas, F., Aguiar, E., Castillo, F. \& Touze-Foltz, N. (2014c). Long-term performance of EPDM geomembrane in El Boquerón reservoir. Geosynthetics International, 21, No. 6, 387-398.

Noval, A. M., Blanco, M., Castillo, F., Leiro, A., Mateo, B., Giroud, J. P., Aguiar, E., Torregrosa, J. B. \& Sánchez, F. J. (2014d). Influence of orientation on ageing of a reinforced PVC geomembrane. 10th International Conference on Geosynthetics, IGS (Germany) German Geotechnical Society, Berlin, Germany, pp. 550-561.

Noval, A. M., Blanco, M., Farcas, F. \& Touze-Foltz, N. (2015). Etude de la durabilité de la geomembrane en EPDM installée dans la retenue d'eau 'El Boquerón'. Proc. 10émes Rencontres Géosyntétiques, CFG - Comité Français des Géosynthétiques, LA Rochelle, France, pp. 399-408 (in French).

Ortega, J. J. \& Blanco, M. (1982). Identificación de compuestos orgánicos por espectroscopia infrarroja. Pub. CEDEX. Monografia M-4. Ed. Safer, CEDEX, Madrid, Spain, p. 100.

PGI (PVC Geomembrane Institute) (2004). PVC Geomembrane Material Specification. P. 1104, University of Illinois, Urbana, IL, USA.

Rowe, R. K., Rimal, S. \& Sangam, H. (2009). Ageing of HDPE geomembrane exposed to air, water and leachate at different temperatures. Journal of Geotechnical and Geoenvironmental Engineering, 136, No. 2, 299-309.

Soriano, J., Blanco, M., Aguiar, E. \& Burgos, J. (2010). La microscopia como método de análisis en el estudio de geomembranas sintéticas de PVC-P. Proc. 3er Congreso Nacional de Impermeabilización: Edificación, Obra Civil y Balsas y 3er Simposio Nacional sobre proyecto, construcción e impermeabilización de balsas, IGS-Spain, Barcelona, Spain, pp. 411-422 (in Spanish).

Soriano, J., Blanco, M., García, M. A., Leiro, A., Mateo, B., Burgos, J., Aguiar, E. \& Rubín de Célix, M. (2012). Optical and scannning electron microscopy as advanced analysis methods to determine the condition of synthetic geomembranes. In Eurogeo5, Vol. 2: 266-273 (Electronic Proceedings) Vol. 1: 475-482 (Printed Volumes), Blanco M, Leiro A, Torregrosa JB et al., Editors, Ed. R. B. Servicios Editoriales, S. L, Valencia, Spain, pp. 102-116.

Stark, T. D., Choi, H. \& Diebel, P. W. (2005). Influence of plasticizer molecular weight on plasticizer retention in PVC geomembranes. Geosynthetics International, 2, No. 12, 99-110.

UNEP DTIE OzonAction Branch \& UNEP/GRID-Arendal (2007). Vital Ozone Graphics, UNEP/GRID-Arendal, Arendal, Norway.

The Editor welcomes discussion on all papers published in Geosynthetics International. Please email your contribution to discussion@geosynthetics-international.com by 15 August 2018. 